\title{
EDITORIAL
}

\section{Navigating interpersonal conflict and peer review}

\author{
Gene P Siegal \\ Laboratory Investigation (2009) 89, 256-258; doi:10.1038/labinvest.2008.160
}

Anatomic Pathology, University of Alabama at Birmingham, Birmingham, AL, USA. Correspondence should be addressed to gsiegal@uab.edu

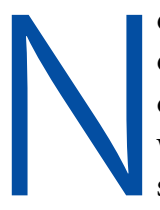
ot too long ago I was invited to serve on a graduate school faculty panel composed of Editors-in-Chief dealing with that most slippery of life's supposedly immutable concepts, ethics as regards the peer-reviewed literature, a growing area of scholarly investigation in its own right. ${ }^{1-3}$ The audience was, in turn, composed of several dozen graduate students pursuing their $\mathrm{PhDs}$ in the life sciences. They were divided into groups, with each team offering a scenario to the panel for their learned and instantaneous opinion.

One could relatively easily and with only a modicum of bombast deal with the standard issues of fraudulent data, conflicts of interest with commercial entities and plagiarism. This was helped in large part by journals codifying their own integrity policies. ${ }^{4}$ Much more worrisome, however, was the surprisingly large percentage of cases that focused on interpersonal relationships, or the lack thereof, in Science, ie, mentors mistreating graduate students, post-doctoral fellows helping each other without appropriate acknowledgment or academic credit, issues of inappropriate sharing of reagents, intellectual property or novel techniques and lastly, academic rivalries extending to the sabotaging of each others work. I and others have previously written about priority in biomedical research, the desire to be first, and the usually mistaken belief that to whomever crosses the finish line first, all credit and glory flows. ${ }^{5}$ If anything this concept has fallen farther into the background as patent positions take on a larger role rather than publication in the peer-reviewed literature. These other alluded to problems, however, seemingly take on a larger and more unhealthy role and are regretfully becoming so common place as being accepted, at least by these young people, as 'the cost of doing business.'

The question then remains as to whether in fact any of this is true. As editors, it is virtually impossible to know because when authors approach editors with charges of failure to include one as a co-author, or inappropriate inclusion of one in that role, more often than not we are forced to push this charge back to them or to their home department, college or institution as there is no way to judge from afar the true merit of such a claim. Although some journals have required each author to spell out in antagonizing detail their exact role in any publication who among us can and will say in the end that this was not an appropriate role meriting authorship if all the other authors agree that it does. ${ }^{6-8}$

The literature itself is surprisingly silent on this world of interpersonal distress as influencing peer review. The International Committee of Medical Journal Editors has as recently as October of last year, updated their uniform requirements for manuscripts submitted to biomedical journals. ${ }^{9,10}$ Others including the WHO have moved down similar pathways. ${ }^{11}$ They have accomplished the seemingly Herculean task of reaching consensus on a host of related topics ranging from authorship to conflicts of interest, the need to publish negative studies and duplicate submissions. Even the Creationist Community has entered the debate with a paper entitled, 'Toward a practical theology of peer review' where they argue 'it is centered in several Christian virtues' and therefore desirable. ${ }^{12}$ At the other end of the spectrum, Rockwell ${ }^{13}$ has argued that the process of peer review itself unleashes a whole series of ethical responsibilities for the reviewer. Although not wishing to minimize or negate these observations, it still begs the central question as to why scholars appear to be at each other's throats with regard to the publishing of scientific articles? Again, true data being remarkably absent.

It is my hypothesis that the answer is straightforward and non-obtuse. One does not have to invoke biblical references to Cain and Abel or a psychosocial rationale for aggressive behavior 
in societies. The answer I put forth to you is that it is the act of publishing itself and by inference the number of publications emanating from any one of us that serves as the surrogate marker for productivity in science and by extension ones worth to academia, industry, government or society. The Dutch have examined risk factors for work-related interpersonal conflicts and identify 'higher levels of job insecurity (as) significantly predicted the onset of conflict.' ${ }^{14}$ We see this all the time now, however minimally masked with expanding debates about citation indices, $\mathrm{H}$-scores and similar 'independent' criteria. ${ }^{15}$ The same issue is often couched in slightly different formats with its own integrity coming into question. ${ }^{16,17}$

All of us who serve as academic mentors are asked all the time, 'How many papers do I need to get promoted'? An hour plus long discussion of what kind of paper, in what kind of journal and whether one was the first, middle or senior author tied back with discussions about teaching quality, clinical practice, grant attainment and service to the institution came back to me full circle with, 'Yes, I understand but how many papers?' I admit that I became so frustrated I finally blurted out ' 26 ' and the young faculty member left now content with a quantifiable although totally arbitrary and ludicrous goal in hand. That we place undue emphasis on the number of publications is, to me, clear. Further, this seems to be done without any documentary evidence that there is a relationship (linear or otherwise) between ones' worth and ones' publications. Lastly, this simple counting seems to suggest that any particular manuscript or project from which it is derived is totally independent of the particular scientific setting that gave birth to its origin.

If you accept my thesis that ones' worth is inappropriately judged by the quantity of ones' publications, and I suspect many will not, for a host of reasons, not the least of which is simplicity. The next obvious question is what to do about it, assuming you believe this behavior is worth changing. I believe the best way is frank, early and complete discussion with all potential interested parties. When approached by a colleague to engage in a research proposal, project or experiment or more commonly when asked to negotiate on behalf on a junior colleague or trainee with a senior investigator, I try to lay out in advance all the expectations (I will derive this clone for you or perform the histopathology, etc.). In exchange, I will (be acknowledged in the manuscript, appear as a co-author on the abstract but not the manuscript, etc.) 'I will pay for the reagents but you will pay the core laboratory charges, etc.' Documenting the key points in writing, it has been concluded, is also often a valuable exercise. When I began this practice decades ago, it seemed very artificial, suggested to some a level of distrust and appeared to most an over-the-top goal-oriented exercise in futility.

Nevertheless, it has served me and my colleagues well. It minimizes any 'gotcha' let down, allows one to plan for expected resources and time, while reinforcing the value of each member of a research team and what he or she brings to the table. In the end, the system of assessing ones' scientific worth is flawed but for those of us who have committed our lives to the sometimes nebulous concept of 'advancing knowledge,' it more clearly helps one understand that this is only accomplished in a community of scholars, each of us tied together to a common end.

\section{ACKNOWLEDGEMENT}

I am indebted to Dr Robert Hardy for his critical reading of the paper and thoughtful insights.

1. Ancker JS, Flanagin A. A comparison of conflict of interest policies at peer reviewed journals in different scientific disciplines. Sci Eng Ethics 2007;13:147-157.

2. Cooper RJ, Gupta M, Wilkes MS, et al. Conflict of interest disclosure policies and practices in peer-reviewed biomedical journals. J Gen Intern Med 2006;21: 1248-1252.

3. Bosetti F, Toscano CD. Is it time to standardize ethics guiding the peer review process? Lipids 2008;43: 107-108.

4. McDonald JM, Eisemann MG, Cox AE. A matter of trust: introducing the journal scientific integrity policy. Am J Pathol 2007;171:1.

5. Siegal GP. Adenomatoid tumors. Adrenal cysts and being first. Arch Pathol Lab Med 1990;114:641-642.

6. Hwang SS, Song $\mathrm{HH}$, Baik JH, et al. Researcher contributions and fulfillment of ICMJE authorship criteria: analysis of author contribution lists in research articles with multiple authors published in radiology. International Committee of Medical Journal Editors. Radiology 2003;226:16-23.

7. Marusić A, Bates T, Anić A, et al. How the structure of contribution disclosure statements affects validity of authorship: a randomized study in a general medical journal. Curr Med Res Opin 2006;22:1035-1044.

8. Ivaniš A, Hren D, Sambunjak D, et al. Quantification of authors' contributions and eligibility for authorship: randomized study in a general medical journal. J Gen Intern Med 2008;23:1303-1310.

9. International Committee of Medical Journal Editors. Uniform requirements for manuscripts submitted to biomedical journals: writing and editing for biomedical publication. Croat Med J 2003;44:770-783.

10. Davidoff F, DeAngelis CD, Drazen JM, et al. International Committee of Medical Journal Editors. Sponsorship, authorship and accountability. N Engl J Med 2001;345:825-826.

11. Gollogly L, Momen H. Ethical dilemmas in scientific publication: pitfalls and solutions for editors. Rev Saude Publica 2006;40:24-29. 
12. Sanders RW, , et al.Wise KP Toward a practical theology of peer review. Answers Res J 2008;1:65-75.

13. Rockwell S. Some thoughts on the ethics of research and publication. Radiat Res 2002;157:1-2.

14. De Raeve $L$, Jansen NW, van den Brandt PA, et al. Risk factors for interpersonal conflicts at work. Scand J Work Environ Health 2008;34:96-106.
15. Ketcham CM, Crawford JM. Can impact factor data be trusted? Lab Invest 2008;88:340-341.

16. Pendlebury DA. Show me the data. J Cell Bio 2007;179:1091-1092.

17. Rossner M, Van Epps H, Hill E. Irreproducible results--a response to Thomson Scientific. J Gen Physiol 2008;131:183-184. 